\title{
The nature and origin of magnetic anomalies over the Gölcük caldera, Isparta, South-Western Turkey
}

\author{
M. N. Dolmaz ${ }^{1}$, E. Oksum ${ }^{1}$, E. Erbek ${ }^{1}$, H. E. Tutunsatar ${ }^{1}$, O. Elitok ${ }^{2}, 2018$ \\ ${ }^{1}$ Suleyman Demirel University, Faculty of Engineering, Department of Geophysical \\ Engineering, Isparta, Turkey \\ ${ }^{2}$ Suleyman Demirel University, Faculty of Engineering, Department of Geological \\ Engineering, Isparta, Turkey
}

Received 18 January 2018

\begin{abstract}
Уперше проведено магнітне знімання, дані якого було перетворено методами повної горизонтальної похідної, виявлення аналітичного сигналу горизонтального градієнта, визначення кута гіперболічного нахилу для ідентифікації похованих вулканічних структур навколо м. Іспарта (Південно-Західна Туреччина). Активність вулкана Гьольджюк відбувалась у кутку трикутника Іспарта на перетині покривів $\lambda$ чіан і Анталья. Вулканізм почався 4,0-4,7 млн років тому переважно виливом лав і закінчився виверженням магми та води у четвертинний період. Район досліджень перекритий автохтонними і алохтонними утвореннями, що інтрудовані пліоценовими і четвертинними породами вулкана Гьольджюк, та вкриті пірокластичним попелом і відкладами лавових потоків. Межі похованої вулканічної структури визначено методами виявлення граней джерела. Геометрія трахітового купола на північний захід від оз. Гьольджюк і його продовження вниз вивчено 2D моделюванням, причому конфігурацію проконтрольовано за результатами визначення глибини спектральним аналізом ізольованої аномалії. Згідно з графіком азимутально усереднених логарифмічних спектрів, продовження вниз глибини залягання джерела трахітового купола сягає 850 м. За результатами розв'язку оберненої задачі горизонтальний розмір моделі цього купола дорівнює 1250 м під земною поверхнею, тоді як над поверхнею - близько 400 м.
\end{abstract}

Ключові слова: Південно-Західна Туреччина, кратер оз. Гьольджюк, вулканізм, магнітні аномалії, поховані вулканічні структури.

Introduction. Since the 1970 many scientific studies have been performed to examine geology, mineralogy, petrography, geochronology, tephrachronology, and industrial properties of the volcanic rocks outcropping around Isparta city [e. g. Alici et al., 1998; Kalyoncuoglu et al., 2010; Platevoet et al., 2008, 2014; Elitok et al., 2010; Schmitt et al., 2014]. However, the subsurface structure of the volcano is unknown due to the cover of volcanic deposits. Therefore, this study is aiming at revealing the deep structure of the Gölcük volcano including an area of about $8 \mathrm{~km}^{2}$ within the Göl- cük crater. For this purpose, we have integrated magnetic anomaly data enclosing the Gölcük Caldera with the objective of identifying possible subsurface structures below the surface cover. The causative bodies of magnetic anomalies are analyzed by utilizing phase filter techniques such as the total horizontal derivative (THD), the horizontal gradient analytic signal (HGAS), and the hyperbolic tilt angle (HTA). We have also constructed a two dimensional (2D) model to reveal the depth extension of the dome structure observable at the surface as well as delineated as a distinct circular anoma- 
ly pattern by the results of the edge detection analysis.

The Geological and Tectonic Setting. Southwestern Turkey is characterized mainly by autochthonous and allochthonous rock units from the Paleozoic to Quaternary. The allochthonous sheets can be subdivided into three main units, i.e. the western Lycian and Antalya nappes and the eastern BeyşehirHoyran-Hadim nappes. The Lycian and Beyşehir-Hoyran-Hadim nappes are separated from the Antalya nappes by the Tauride carbonate axis, including the western, NE-trending Bey Daglari carbonate axis and the eastern, SE-trending Anamas-Akseki carbonate axis. Along these carbonate axes a northpointing cusp, the Isparta Angle, occurs. The study area and its environs are covered by authochtonous and allochthonous units that are intruded by the Pliocene and Quaternary Gölcük volcanics and also overlain by pyroclastic fall and flow deposits (Fig. 1). The Gölcük volcano (Isparta) is situated at the apex of the Isparta Angle, especially at the intersection of the Lycian and Antalya nappes in the North. These allochthonous systems were thrusted onto the Bey Daglari platform as a system of converging nappes [Altinli, 1945], in two steps: at first, the Antalya nappes (from the southeast), in the Late Cretaceous-Palaeocene times, and in a second time the Lycian nappes (from the north) reached their present position in the mid-Miocene times (mid-Langhian). These nappes are superposed in the south of Isparta area [Poisson et al., 2003 b]. However, the complete collision between the continental blocks and the complete closure of the Isparta Angle occurred only in late Miocene and mid-Pliocene times as a consequence of the Aksu thrust [Poisson et al., 2003a]. After this last period of compression (from east to west), the area was the site of extensional tectonics, which gave way to the formation of extensional basins around the apex of the Isparta Angle and to the initiation of the volcanic activity.

Volcanic activity around Isparta city initiated between $4-4.7$ my ago [Lefevre et al., 1983] mainly as lava domes and dykes of trachytic, trachyandesitic, basaltic trachyandesitic composition and continued up to Quaternary time, discontinuously. The volcanism ended with phreatoplinian eruptions including three main eruptives cycles. Cycle I, represented by more than 200 m-thick pyroclastic flow deposits occasionally separated by paleosoils and corresponding to caldera-forming ignimbritic eruptions. Cycle II, consisting of tephriphonolite lava dome-flows extruded throughout the caldera and currently found along the rims of the present crater. Cycle III made up of tuff ring deposits related to several phreatoplinian eruptions of a maar-type volcanic activity ended with trachytic domes protruding within the maar crater [Platevoet et al., 2008]. Ash/ pumice fall deposits can be traced uninterruptedly to the north towards the city of Isparta. In the article [Elitok et al., 2010] classified the volcanic rocks around Isparta settlement area as (i) Pliocen extracaldera lavas comprising lamprophyre (minette), basaltic trachyandesite, trachyandesite, and trachyte and (ii) intracaldera lavas and pyroclastics (ignimbrite flows and ash/pumice fall deposits) formed during the Quaternary. The present-day volcanic landforms just around the Gölcük lake have been created by the last phreatoplinian eruptions of a maar-type volcanic activity (cycle III), which ended with trachytic domes protruding within the maar crater. The crater edge mainly consists of remnants of tephriphonolitic lava flow-domes rimming the central depression occupied by the Gölcük Lake. Two recent intracaldera-like trachytic domes occupy the south-central part of the crater (Fig. 2).

Data and Methods. The ground magnetic data were collected using Geometrix G856 proton magnetometer at $250 \mathrm{~m}$ intervals. The location of each station was determined by using GPS. A second proton magnetometer (Geometrix G856) monitored the diurnal variation at a base station during the survey and the measurements were also subtracted from the observed magnetic data to remove the effects of the possible abrupt changes of the Earth's magnetic field from the data. The results are residual total magnetic field ano- 


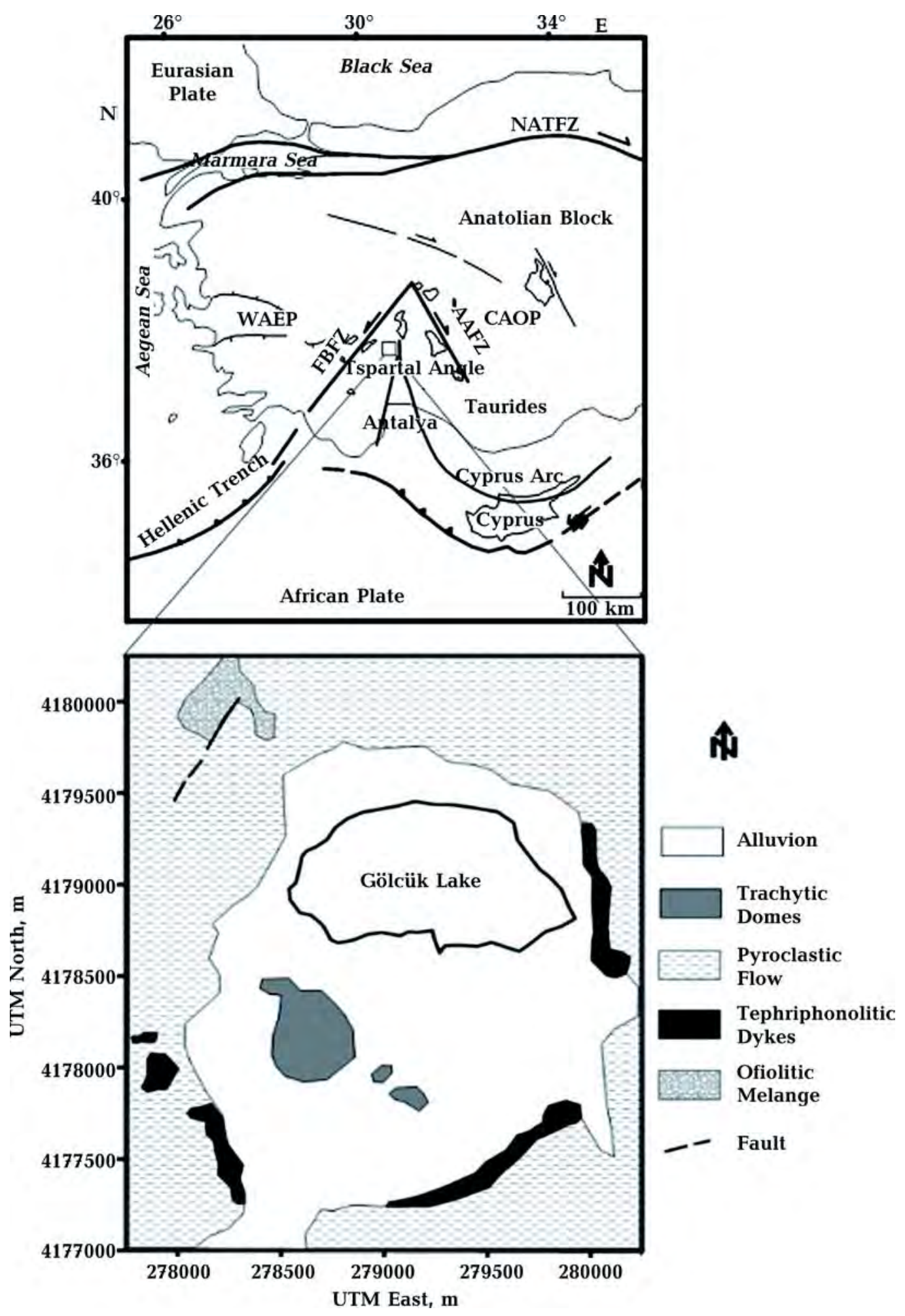

Fig. 1. Simplified tectonic map of western Turkey and adjoining regions (modified from [Dolmaz, 2007]). Geological details of the study area are given below (modified from [Alici et al., 1998]). Abbreviations: NATFZ, North Anatolian Transform Fault Zone; FBFZ, Fethiye-Burdur Fault Zone; AAFZ, Afyon-Aksehir Fault Zone; WAEP, West Anatolian Extensional Province; CAOP, Central Anatolian Ova Province. Coastlines and lakes are also shown. 


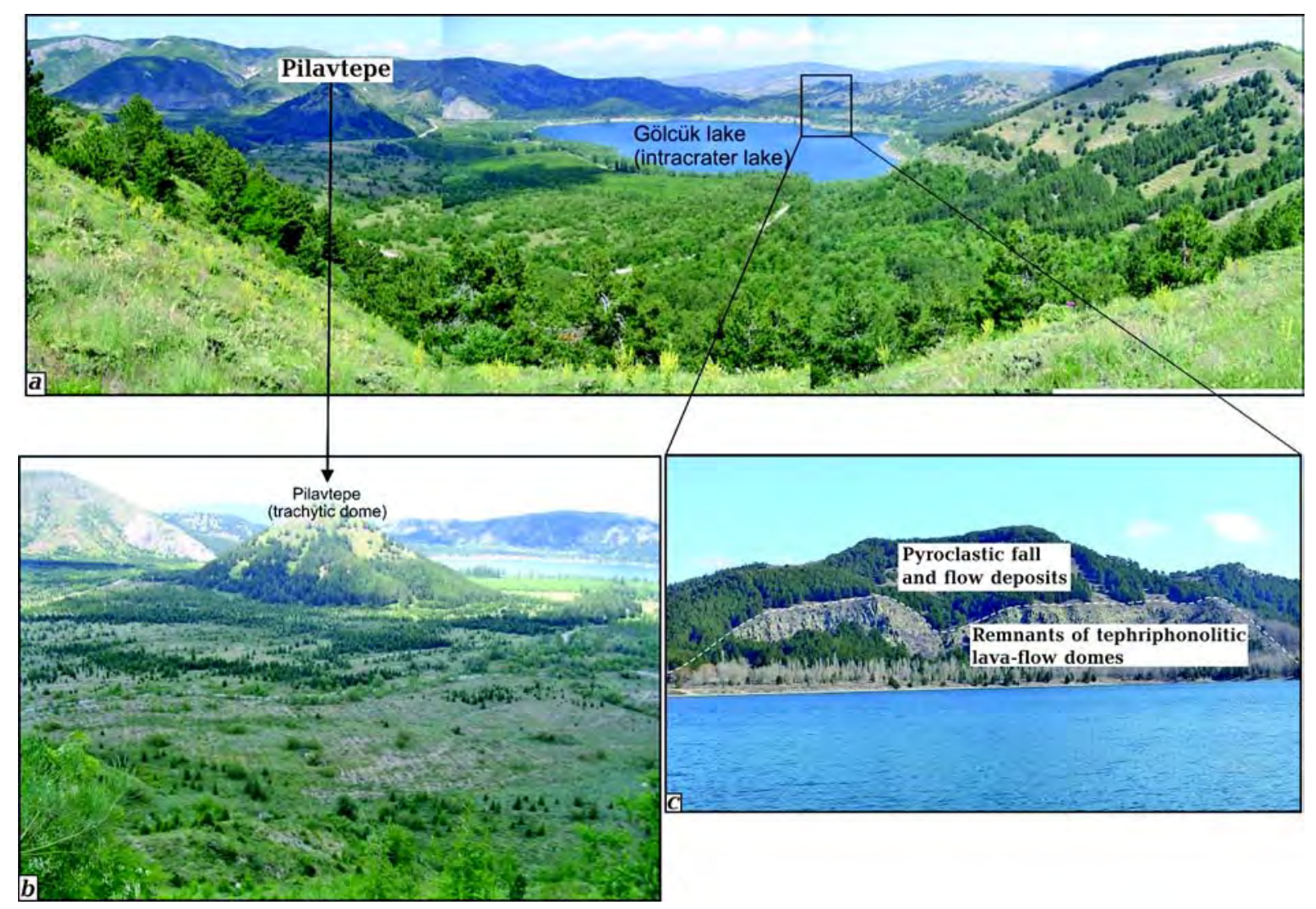

Fig. 2. Panoramic view from the Gölcük maar crater $(a)$, trachytic dome (Pilav tepe) protruding within the crater $(b)$, remnants of the tephriphonolitic lava-dome flows rimming the crater $(c)$.

malies that are caused by variation of magnetization of rocks or magnetic structures.

Since the inclination/declination pair of the Earth's magnetic field is $57^{\circ} / 4^{\circ}$ in this region, the magnetic anomalies caused by magnetic bodies do not occur over the center of the sources. Due to this reason, the total field magnetic data first were transformed into the magnetic pole [Baranov, 1957], producing a reduced to pole (RTP) magnetic map where the highs are located more directly on their causative source and lows are suppressed or eliminated (Fig. 3). The body magnetization direction was assumed to be equal to the Earth's magnetic field. The values of the calculated RTP anomaly contours vary between $\pm 1000 \mathrm{nT}$.

Total Horizontal Derivative (THD). One important aim in the interpretation of magnetic data is to determine the type and the location of the magnetic sources. There ha- ve been developed numbers of a method to determine the location of magnetic sources. The edge-detection methods (EDM) mainly include the THD. The amplitude function of the THD is defined as the square root of the squared sum of the two horizontal derivatives of the magnetic field anomaly given by [Cordell, 1979]:

$$
\mathrm{THD}=\sqrt{\left(\frac{\partial M}{\partial x}\right)^{2}+\left(\frac{\partial M}{\partial y}\right)^{2}},
$$

where $M$ is the magnetic field. The THD map obtained from the RTP data via Equation 1 is shown in Fig. 4.

\section{Honizontal Gradient Analytic Signal (HGAS).}

The HGAS is one of the methods applying at recent years, which allows determining sensitively boundaries of structures and primarily has been applied to a large area in 


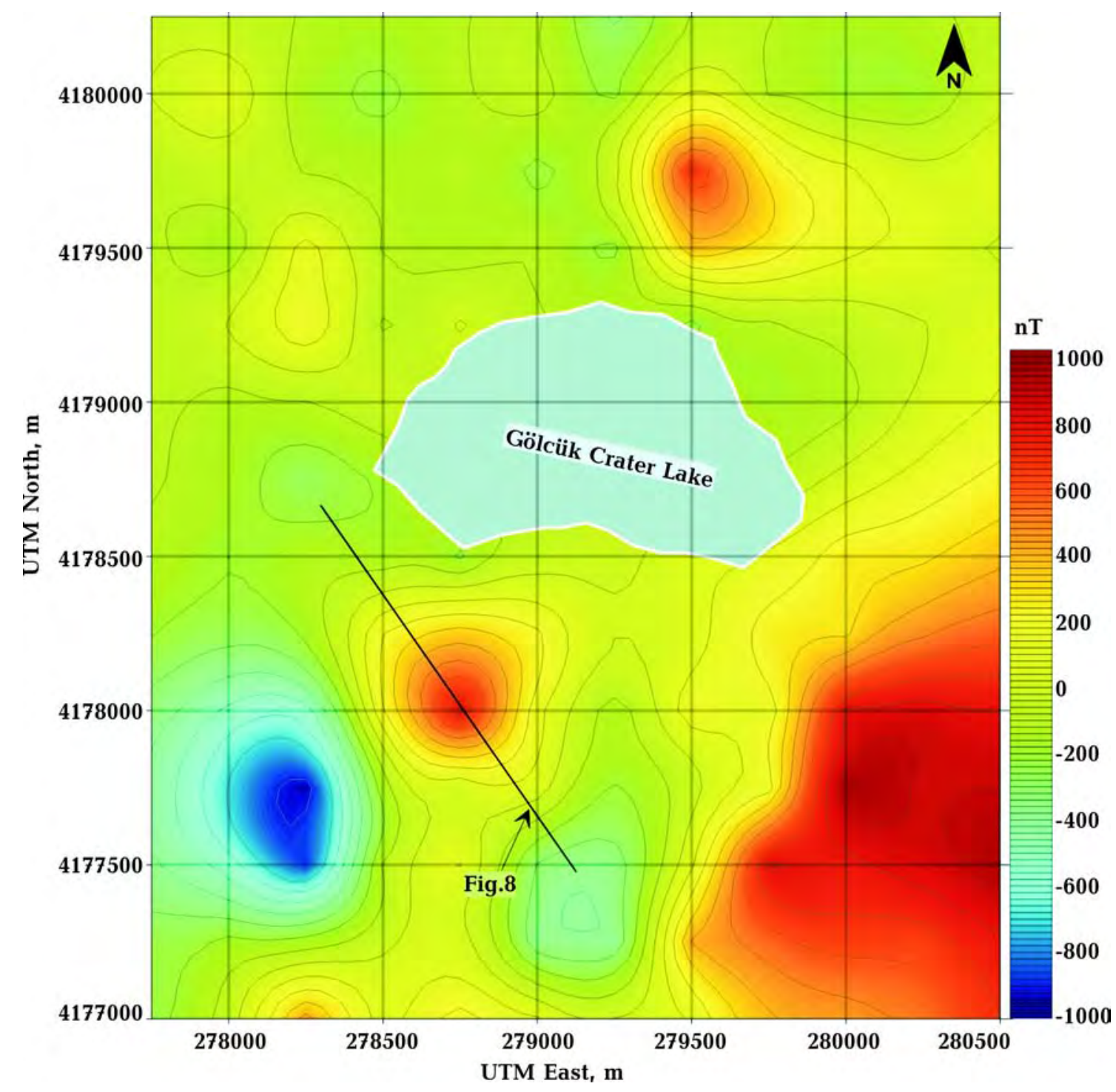

Fig. 3. Reduced to pole (RTP) total field magnetic anomaly map of the study area. Contour interval is $100 \mathrm{nT}$. The NW-SE cross-section shows the location of the anomaly profile to be interpreted 2D modeling.

Eastern Mediterranean [Erbek, Dolmaz, 2014]. In the article [Bournas, Baker, 2001] implied that HGAS gets better results than the resolution of the simple analytic signal (AS). They also implied that this method provides advantages while defining the boundaries of causative structures due to the fact that it is not affected by the direction of Earth's magnetic field. HGAS method is given by [Bournas, Barker, 2001] as,

$\mathrm{HGAS}=\sqrt{\left|A S_{x}(x, y)\right|^{2}+\left|A S_{y}(x, y)\right|^{2}}$ where

$$
\begin{gathered}
A S_{x}(x, y)= \\
=\sqrt{\left(\frac{\partial M_{x}}{\partial x}\right)^{2}+\left(\frac{\partial M_{x}}{\partial y}\right)^{2}+\left(\frac{\partial M_{x}}{\partial z}\right)^{2}} \\
A S_{y}(x, y)= \\
=\sqrt{\left(\frac{\partial M_{y}}{\partial x}\right)^{2}+\left(\frac{\partial M_{y}}{\partial y}\right)^{2}+\left(\frac{\partial M_{y}}{\partial z}\right)^{2}}
\end{gathered}
$$




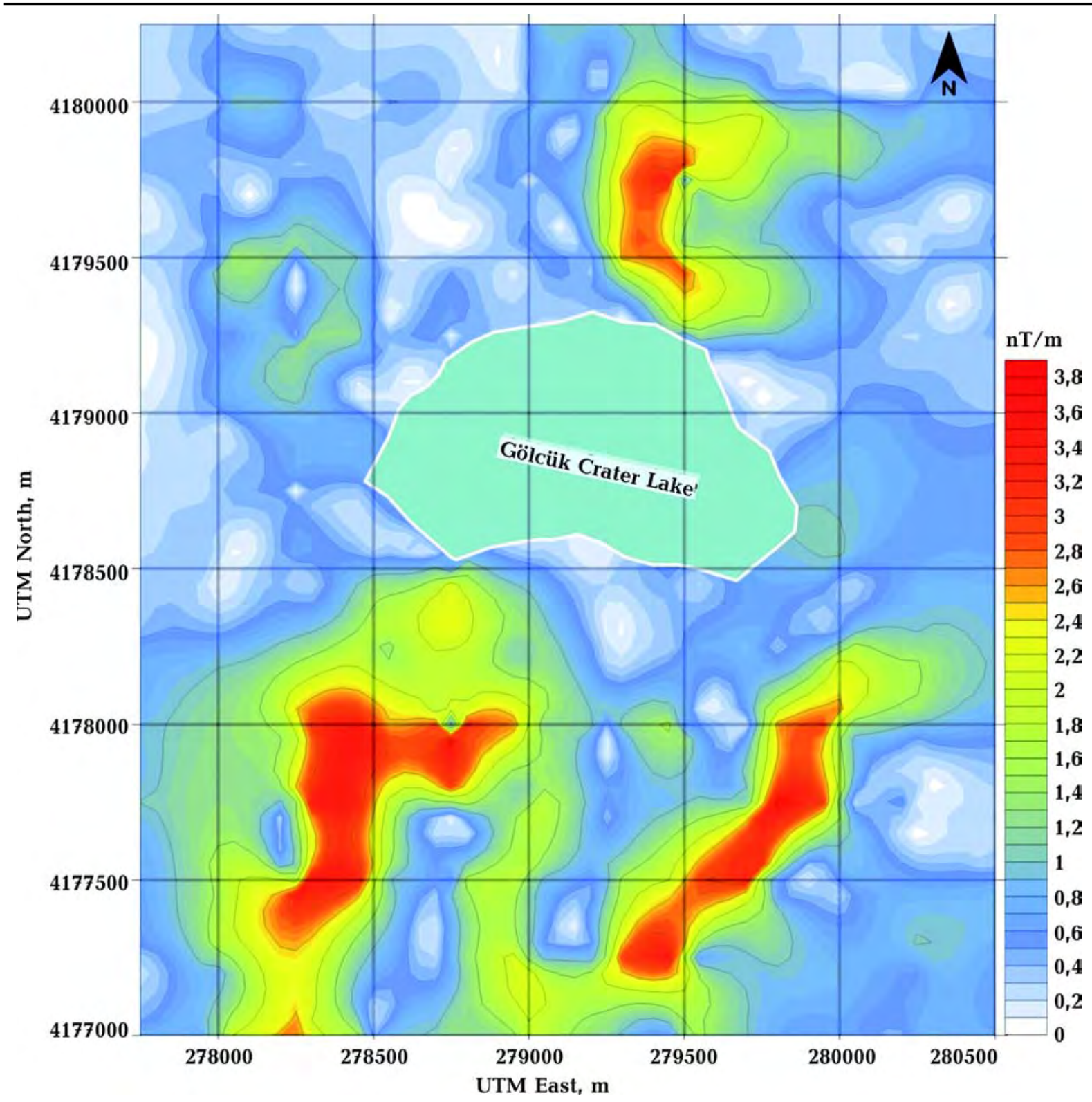

Fig. 4. Total horizontal derivative (THD) map computed using Equation (1).

$M_{x}$ and $M_{y}$ are the derivatives of potential field data in $x$ and $y$ directions. The HGAS map via Equation 2 is shown in Fig. 5.

Hyperbolic Tilt Angle (HTA). According to [Cooper, Cowan, 2006], the usage of the real part of the hyperbolic tangent function in the tilt angle calculation achieved better delineation of the edges of the body than the other filters such as the THD, THDR, and Theta map. The real part of the hyperbolic tangent function is given as

$$
\mathrm{HTA}=\Re(\operatorname{arctanh}(\partial M / \partial z) /
$$

$$
\left./\left((\partial M / \partial x)^{2}+(\partial M / \partial y)^{2}\right)^{1 / 2}\right) .
$$

In the article [Cooper, Cowan, 2006] showed that the maximum value of the HTA gives the improved location of the body edges. It is expected that the tilt angle is positive when over the source, passes through zero when over, or near, the edge where the vertical derivative is zero and the horizontal derivative is a maximum and negative outside the source region. The HTA map via Equation 5 is shown in Fig. 6. 


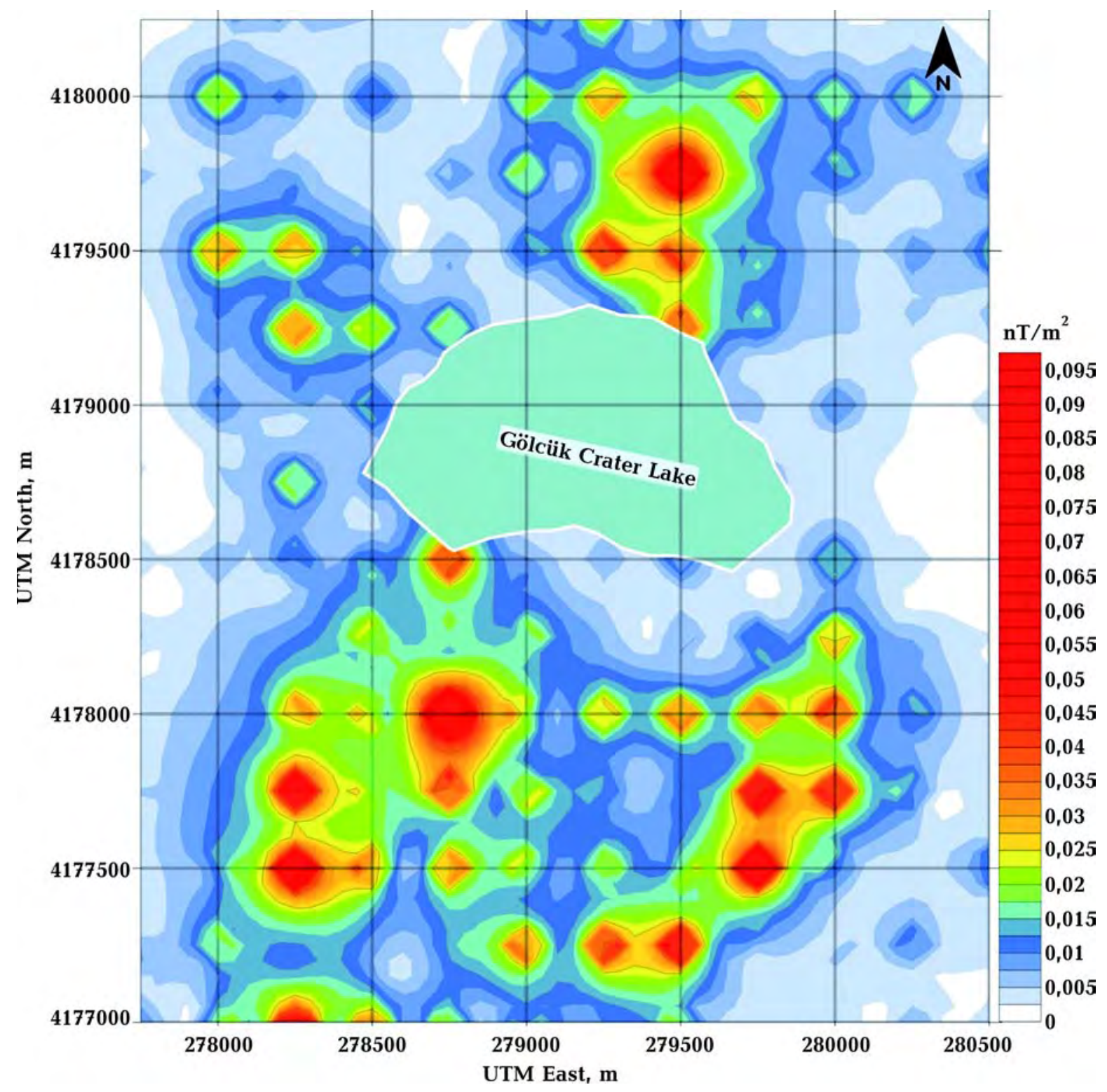

Fig. 5. Horizontal gradient analytic signal (HGAS) map computed using Equation (2).

Depth analysis and two dimensional (2D) modelling. In order to determine the mean depths for interfaces of significant susceptibility contrasts in the crust, we applied the spectral factorization method [Spector, Grant, 1970]. An examination of the RTP magnetic anomalies given in Fig. 3 shows that the strongest anomaly is concentrated mainly in the pillow lava in the SW Gölcük crater lake. To define the geometry of this dominant causative body, a NW-SE profile data was taken on the RTP magnetic anoma- ly map (see Fig. 3). Fig. 7 shows the azimuthally-averaged log power spectrum of the RTP magnetic data. As a result of the power spectrum, source depth of the causative body was found as $0.85 \mathrm{~km}$.

A 2D model is constructed from the extracted profile by using the technique suggested by [Talwani, Heirtzler, 1964] based on modelling of arbitrarily shaped bodies. In-situ susceptibility measurements were carried out using a KT10 susceptibility meter. According to the measurement results, a sus- 


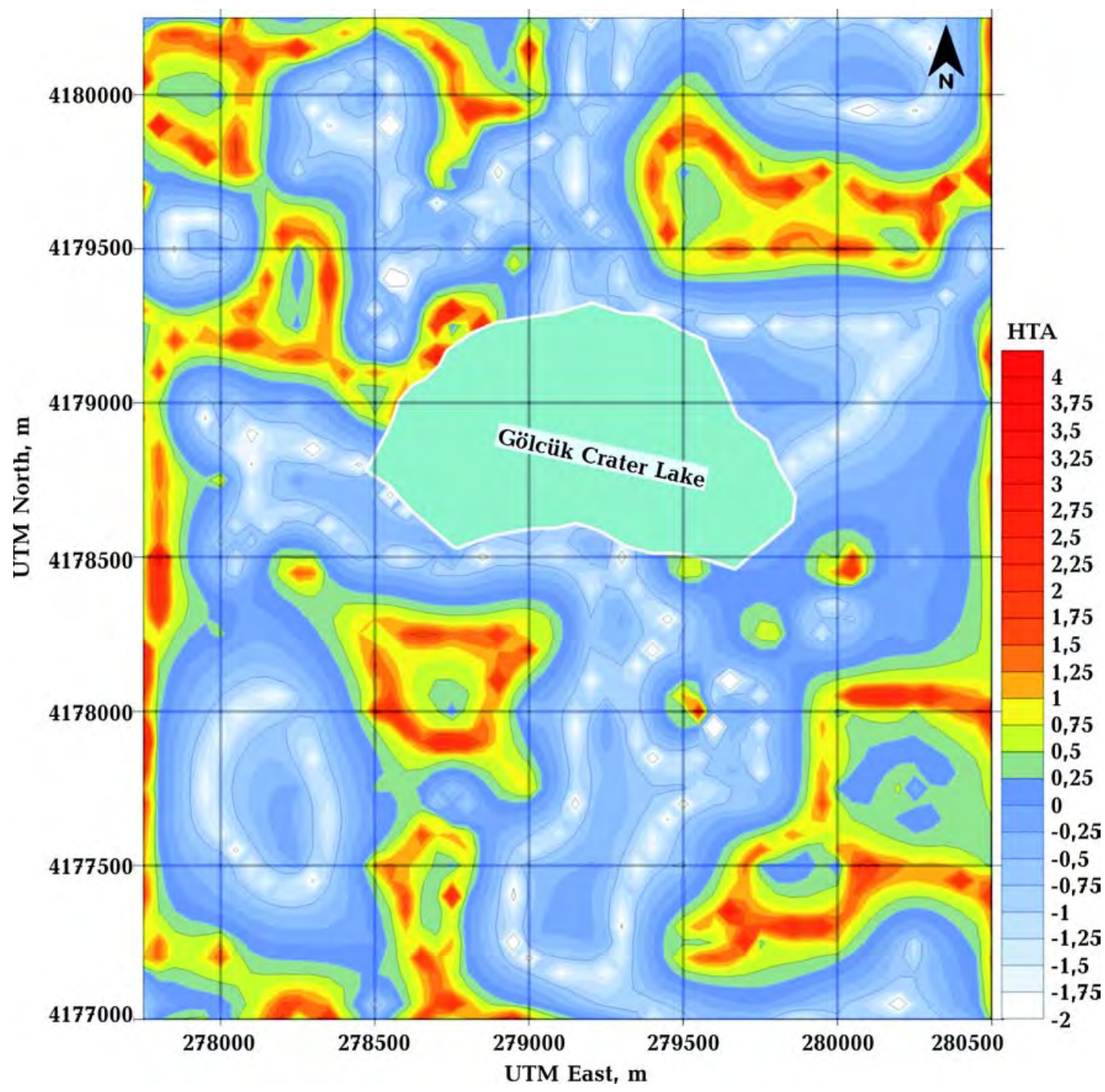

Fig. 6. Hyperbolic tilt angle (HTA) map computed using Equation (5).

ceptibility contrast of $2.7 \cdot 10^{-3}$ emu was used in calculating the forward magnetic anomaly of the model (Fig. 8). The forward modelling process was continued with the control of the power spectrum depth until the best fit was obtained between the observed and calculated anomalies.

Results and Discussion. In this paper, it is aimed to investigate subsurface structures over the Gölcük caldera area by using the ground magnetic anomaly data. For this purpose, we prepared various integrated anomaly maps based on magnetic anomalies. As a standard process of interpre- tation of magnetic anomalies, the total field magnetic data were reduced to the magnetic pole (RTP) and contoured to produce the RTP magnetic anomaly map shown in Fig. 3. To determine the locations and boundaries of the causative bodies, the THD, the HGAS, and the HTA methods were applied to the obtained RTP anomaly data.

The THD map reveals three main magnetic closures within anomaly values reaching up to a maximum of $3.8 \mathrm{nT} / \mathrm{m}$ (see Fig. 4). Two large anomalies are observed on the south of Gölcük Crater Lake in NNE-trending, whereas another one is observed to the 


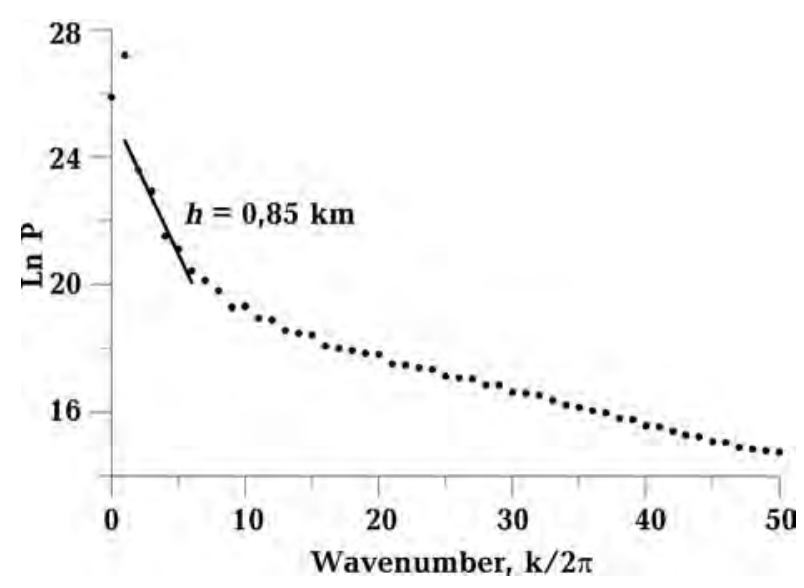

Fig. 7. Power spectrum graph of the magnetic anomaly profile, in Fig. 3, caused by the trachytic dome in SW of the lake.

NE of the lake in N-trending (see Fig. 4). This evidence is also consistent with the results obtained from the HGAS map where high values, up to $0.095 \mathrm{nT} / \mathrm{m}^{2}$ are observed SW, SE and NE of the Gölcük Caldera (see Fig. 5).

The range of values on the HTA map is between -2.0 and 4.0 (see Fig. 6). Here, the negative contours surrounding the ca-

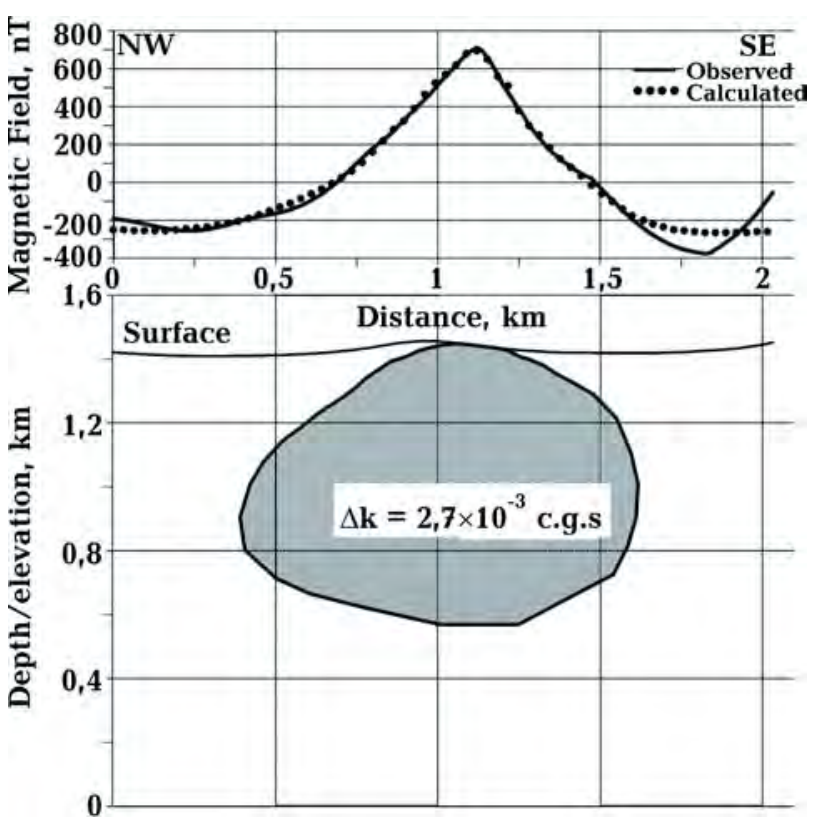

Fig. 8. 2D magnetic model along the profile in Fig. 3. usative bodies are complication in the interpretation. The value of 1.0 was selected as a threshold value for the interpretation of the body edges. According to this, the high values of the HTA provide the best resolution of the edges of basement magnetic sources when compared with the THD and HGAS. The N-trending anomaly the NE of Gölcük lake seen in the THD and HGAS maps appears as extended eastward in the HTA map (see Fig.6). While there is not any revealed anomaly in the THD and HGAS maps, a number of striking anomalies are noted on the HTA map in the NW of the lake. In addition, while the SW of the lake the structural boundaries of the dome are not observed distinctly on the THD and HGAS maps, the boundaries are more explicit in the HTA map. In the SE of the lake, the NE trending anomaly, which is seen on the THD and HGAS maps (see Fig. 4, 5), is also seen as improved on the HTA map (see Fig. 6).

All of the derived maps and obtained results were correlated with each other. It has been thought that two anomalies on the THD, HGAS and HTA anomaly maps situated in the northern part and SE of Gölcük Caldera are caused by tephriphonolitic dykes. However, the anomaly source located in the northern part has not been observed on the surface geology map due to the fact that the causative structure is covered by pyroclastic units. Whereas, the magnetic influence of the trachytic dome located SW of Gölcük Caldera has been observed distinctly on all anomaly maps (see Fig. 4, 5, 6). This isolated anomaly concentrated over the pillow lava was interpreted in terms of its shape and depth extension using an NWSE cross-section magnetic data. The azimuthally-averaged logarithmic power spectra plot indicates that the source depth of the trachytic dome which produces the high magnetic anomalies is buried at $0.85 \mathrm{~km}$ below the surface (see Fig. 7). The geometrical shape and the downward continuation of this dome structure have been modelled. With the control of the power spectrum depth result, the model constructed by the best fit 


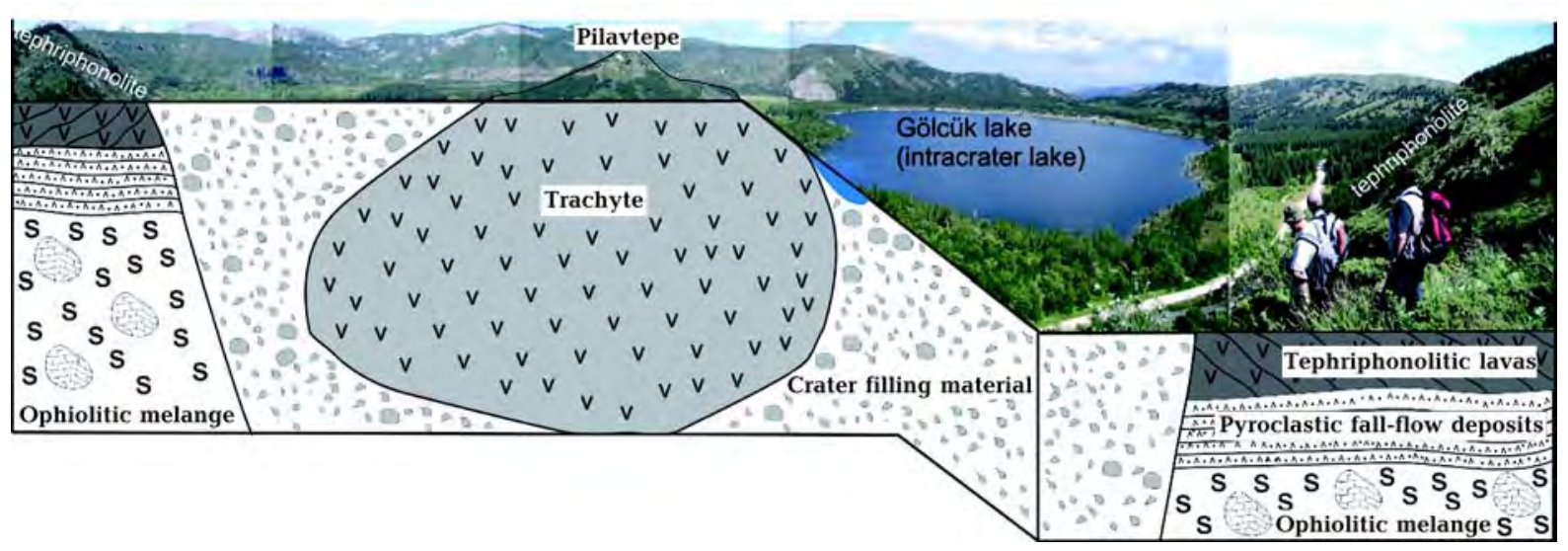

Fig. 9. View of the Gölcük crater and its subsurface structure deduced from the geophysical data.

between the observed and calculated anomalies reveals that the depth of the dome structure is reasonable when compared with the wavelength of its magnetic anomaly (see Fig. 8). According to the geometrical structure of the obtained model for the source causing the anomaly, the horizontal size and the vertical continuation of this trachytic dome are $1250 \mathrm{~m}$ and $850 \mathrm{~m}$ respectively, with its ellipsoidal shape. When geophysical data fit the field, subsurface structure of the Gölcük crater can be interpreted as is seen in Fig. 9.

Conclusions. The Gölcük volcano, located to the southwest of the Isparta settlement area, is one of the young explosive volcanoes in Turkey. A trachytic lava dome was formed within the Gölcük volcano at the end of phreato-plinian eruptions during Quaternary time. To investigate the geo- metry of this trachytic dome and its downward continuation, we prepared various integrated anomaly maps based on magnetic anomalies. The azimuthally-averaged logarithmic power spectra plot indicates that the downward continuation of source depth of the trachytic dome reaches up to $850 \mathrm{~m}$. The forward inversion results indicate that the horizontal size of the model for this trachytic dome is $1250 \mathrm{~m}$ beneath the surface while it's surface extension is only about $400 \mathrm{~m}$.

Acknowledgments. We would like to thank the Department of Geophysical Engineering of Suleyman Demirel University for providing technical support during the field work. We gratefully acknowledge Prof. O. M. Rusakov (Institute of Geophysics, NAS of Ukraine, Kiev) for constructive suggestions and encouragement. 


\title{
The nature and origin of magnetic anomalies over the Gölcük caldera, Isparta, South-Western Turkey
}

\author{
M. N. Dolmaz, E. Oksum, E. Erbek, H. E. Tutunsatar, O. Elitok, 2018
}

For the first time, ground magnetic survey was performed which data were inverted by means of total horizontal derivative, horizontal gradient analytic signal, and hyperbolic tilt angle techniques to identify subsurface volcanic structures around Isparta city (South-Western Turkey). Here, Gölcük volcanism took place at the apex of the Isparta Angle at the intersection of the Lycian and Antalya nappes. It initiated between 4.0-4.7 my ago mainly as lava extrusions and ended with phreatoplinian eruptions during Quaternary time. The study area is covered by authochtonous and allochthonous units that are intruded by Pliocene and Quaternary Gölcük volcanics and also overlain by pyroclastic fall and flow deposits. The boundaries were revealed for the buried volcanic structure from the edge detection methods. The geometry of the trachytic dome southwestern of the Gölcük Lake and its downward continuation were studied by 2D modelling with the control of the power spectrum depth results applied to the focused anomaly. The azimuthally-averaged logarithmic power spectra plot indicates that the downward continuation of source depth of the trachytic dome reaches up to $850 \mathrm{~m}$. The forward inversion results indicate that the horizontal size of the model for this trachytic dome is $1250 \mathrm{~m}$ beneath the surface while it's surface extension is only about $400 \mathrm{~m}$.

Key words: South-Western Turkey, Gölcük Lake crater, volcanism, magnetic anomalies, subsurface volcanic structures.

\section{References}

Alici P., Temel A., Gourgaud A., Kieffer G., Gündogdu M.N., 1998. Petrology and geochemistry in the Gölcük area (Isparta, SW Turkey): Genesis of enriched alkaline magmas. J. Volcanol. Geoth. Res. 85, 423-446. doi: 10. 1016/S0377-0273(98)00065-1.

Altinli E., 1945. Etude tectonique de la region d'Antalya: Revue de la Faculte' des Sciences Universite' d'Istanbul, Istanbul B10, 60-67.

Baranov V., 1957. A new method for interpretation of aeromagnetic maps: pseudo gravimetric anomalies. Geophysics 22 (2), 359-383.

Bournas N., Baker H.A., 2001. Interpretation of magnetic anomalies using the horizontal gradient analytic signal. Annals of Geophysics 44(3), 505-526. doi: doi: https://doi.org/10. $4401 / \mathrm{ag}-3572$.

Cooper G.R.J., Cowan D.R., 2006. Enhancing potential field data using filters based on the local phase. Computer \& Geosciences 32, 15851591. doi: 10.1016/j.cageo.2006.02.016.
Cordell L., 1979. Gravimetric expression of graben faulting in Santa Fe country and the Espanola basin, New Mexico. In: R. V. Ingersoll (ed.), Guidebook to Santa Fe country. New Mexico Geol. Sot. Guidebook. $30^{\text {th }}$ Field Conference, P. 59-64.

Dolmaz M.N., 2007. An aspect of the subsurface structure of the Burdur-Isparta area, SW Anatolia, based on gravity and aeromagnetic data, and some tectonic implications. Earth Planets Space 59, 5-12. https://doi.org/10. 1186/BF03352016.

Elitok Ö., Özgür N., Drüppel K., Dilek Y., Platevoet B., Guillou H., Poisson A., Scaillet $S_{\text {., }}$ Satir M., Siebel W., Bardintzeff J.-M., Deniel C., Yilmaz K., 2010. Origin and geodynamic evolution of late Cenozoic potassium-rich volcanism in the Isparta area, southwestern Turkey. International Geology Review 52 (4-6), 454-504.

Erbek E., Dolmaz M.N., 2014. Geophysical researches (Gravity and Magnetic) of the Era- 
to-sthenes Seamount in the Eastern Mediterranean Sea. Acta Geopyhsica 62 (4),762784.

Kalyoncuoglu U.Y., Anadolu N.C., Baykul A., Erek $Y$., 2010. Isparta sehir merkezi yüzey topragindaki radyoaktivite düzeyi. Süleyman Demirel Üniversitesi Fen Bilimleri Enstitüsü Dergisi 14(1), 111-119.

Lefevre C., Bellon H., Poisson A., 1983. Pre'sences de leucitites dans le volcanisme Plioce'ne de la region d'Isparta (Taurides occidentales, Turquie). Comptes-Rendus de l'Acade'mie des Sciences 297 (2), 367-372.

Platevoet B., Elitok Ö., Guillou H., Bardintzeff J.-M., Yagmurlu F., Nomade S., Poisson A., Deniel $C_{\text {., }}$ Özgür N., 2014. Petrology of Quaternary volcanic rocks and related plutonic xenoliths from Gölcük volcano, Isparta Angle, Turkey. Origin and evolution of the high-K alkaline series. Journal of Asian Earth Sciences 92, 5376. doi: 10.1016/j.jseaes.2014.06.012.

Platevoet B., Scaillet S., Guillou H., Blamart D., Nomade S., Massault M., Poisson A., Elitok O., Özgür N., Yagmurlu F., Yilmaz K., 2008. Pleistocene eruptive chronology of the Gölcük volcano, Isparta Angle, Turkey. Quaternaire 19(2), $147-156$.
Poisson A., Wernli R., Sagular E.K., Temiz H., 2003a. New data concerning the age of the Aksu Thrust in the south of the Aksu valley, Isparta Angle (SW Turkey): consequences for the Antalya basin and the Eastern Mediterranean. Geological Journal 38, 311-327. https:/ /doi.org/10.1002/gj.958.

Poisson A., Yagmurlu F., Bozcu M., Sentürk M., $2003 \mathrm{~b}$. New insights on the tectonic setting and evolution around the apex of the Isparta Angle (SW Turkey). Geological Journal 38, 257-282. https://doi.org/10.1002/gj.955.

Schmitt A.K., Danišík M., Siebel W., Elitok Ö., Chang, Y.-W., Shen, C.-C., 2014. Late Pleistocene zircon ages for intracaldera domes at Gölcük (Isparta, Turkey). J. Volcanol. Geoth. Res. 286, 24-29. doi: 10.1016/j.jvolgeores.2014. 08.027 .

Spector A., Grant F.S., 1970. Statistical models for interpreting aeromagnetic data. Geophysics 35, 293-302.

Talwani M., Heirtzler J. R., 1964. Computation of magnetic anomalies caused by two-dimensional structures of arbitrary shape. In: Computers in the Mineral Industries. Standford Univ. Publ. Geol. Sci., P. 464-480. 